\title{
Practicality of APOS-Mathematics Worksheet to Improve Student's Mathematical Communication Ability of Seventh Grade Students in Junior High School
}

\author{
Yerizon \\ Departement of Mathematics \\ UNP Padang \\ Padang, Indonesia \\ yerizon@yahoo.com
}

\author{
Edwin Musdi \\ Departement of Mathematics \\ UNP Padang \\ Padang, Indonesia \\ Win_musdi@yahoo.co.id
}

\begin{abstract}
Mathematical communication ability of students allows them to be able to communicate ideas or mathematical ideas with symbols, table, diagrams, or other media to clarify the situation or problems and discuss them with others. But, based on the observation students have difficulty in communicating their ideas. Mathematical communication ability of students needs to be improved. It is suspected to do with the learning of mathematics based of APOS mental constructions. This study tries to developed mathematics worksheet based of APOS mental construction. The students had been given instructions that guide them to understand the studied material. The next process, student had to repeat activities that had been performed previously using different examples. Then the student concluded from the two activities that had been done. The final scheme, students find the relationship of the material that had been studied. The purpose of this study is to develop Student's Work Sheet based of APOS for seven Grade Students of Junior High School that are valid, practical, and effective. This research is the development research using Plomp's Model which consists of three phases, preliminary research, development or prototyping phase, and assessment phase. This research finds that the Worksheet is valid and practices.
\end{abstract}

Keywords-APOS; Mathematical communication;

worksheet

\section{INTRODUCTION}

Communication skill is one of the goals of learning mathematics in high school. Communication is a crucial part of mathematics. The mathematical communication skills of the learners enable learners to communicate ideas or mathematical ideas with symbols, tables, diagrams, or other media to clarify circumstances or problems and discuss them with others.
Based on the results of previous research, it found that the learners have difficulty in explaining the idea of mathematics both orally and in writing from the given problem. Many learners cannot be able to write down the process in solving the problem in a row.

The ability of mathematical communication can be built through the process of training and habituation done continuously [1]. To improve the mathematics communication skills of learners, it is necessary to support them by learning process that leads them to construct their own knowledge and perform these activities repeatedly. If this is done repeatedly, learners can understand the subject matter and are able to communicate their knowledge.

The implementation of learning to improve students' communication skills of mathematics should be supported by the availability of learning resources. One of the learning resources used by learners to obtain learning information is arranged in the form of Student Worksheet (LKPD). LKPD usually contain lesson material which is organized systematically and regularly. Through LKPD, teachers can direct activities to be carried out by learners. Preparation of LKPD is done by considering the characteristics, materials and cognitive abilities of learners.

One of the learning models that can improve the communication skills of mathematics is the mental construction of APOS. As according to [2], APOS theory can be used to improve high level mathematical ability, one of them is the ability of math communication. The APOS (action-process-objectschema) construction theory is developed by Dubinsky and his colleagues. APOS theory embraces the social constructivism developed by Vygotsky called social constructivism. The students' mathematical knowledge and understanding 
determine as a result of their construction and their interaction with others in understanding mathematical ideas and their mental constructions in understanding mathematical ideas [2].

The mental construction theory of APOS consists of four aspects. Action is a transformation of mental objects to acquire other mental objects. When the action is repeated, the action will be integrated into the process. Then, the individual will realize that transformation (action and process). it can be done and actually it construct the transformation, then the individual interpret the process as the object. A collection of integrated actions, processes and objects is called scheme. Through these activities the mental construction-based learning model of APOS constructs mental or compiles a representation in understanding a concept.

[3]found in his research entitle the application of Modification-Action Learning Model, Prosess, Object and Schema (M-APOS) that it can improve the understanding of Mathematical Concept of Learners. In line with that,[4] found that the developed LKPD can improve the learning process and learning outcomes of learners. However, this research will focus on the practicability of APOS-based learning media.

\section{RESEARCH METHODS}

This research is development research that is used to develop a student worksheet. Development research is used to produce a particular product, and test the effectiveness of the product. The first phase is the Prototyping and Development Phase (Development and Prototyping Phase). In this phase self evaluation and expert reviews are held to examine the validity of the designed worksheet. Self evaluation is done to evaluate its own prototype. Based on the evaluation results it is revised. Once the prototype is believed to be good, and as expected, the next stage is expert reviews. Revision continues until the worksheet is valid. If the worksheet is valid then it is followed by one-to-one evaluation. Evaluation process does not ask the three students who provide commentary on the worksheet but different students. Based on the evaluation, revision is held to the worksheet. After the worksheet was revised based on feedback on a one-toone evaluation, it was tried out to the limited group (small group). This try out is performed on conditions which are similar to actual conditions. Field trials conducted to look at the practicalities of the worksheet that had been designed. Practicalities of the worksheet are the level of use of the worksheet by the user. Practicalities can be seen during the implementation of learning through observation, interviews and questionnaires.

\section{RESULTS AND DISCUSSION}

The practice of LKPD is done through the evaluation of one-to-one and small group. The subjects of one-toone evaluation are 3 students, each of which is drawn from high-level, moderate and low-ability learners. This one-to-one evaluation aims to see if the language used is understandable for learners. It is also useful to see if the developed LKPD is appealing to learners. This one-on-one evaluation is conducted by asking learners to understand and to do the activities contained in the LKPD. Learners work independently. When students do the LKPD, researchers observe the activities of participants and provide assistance when students experience obstacles. If obstacles are experienced by learners, a field note is made by researchers which are useful for LKPD improvement. This research finds some typographical errors and student difficulties in drawing a flat wake and the picture is too small.

Small group evaluation is carried out on 8 students of class VII SMP in 6 times of meetings. Researchers act as teachers as well as observers in this small group evaluation, but there is also another observer. Furthermore, learners are asked to do the exercises. In the first and second LKPD learners found few difficulties when working on questions number one and three. This is because learners are not accustomed to working on communication skills. The teacher is given a little direction that learners should start from the known information. Then, it develop using the rectangular and square properties that they have found.

Practicality of learning derived from the questionnaire filled by the learner after carrying out small group evaluation and calculation. The results of the questionnaire of practicality can be seen in Table 1 below.

TABLE I. CALCULATION RESUltS OF PRACTICAL QUESTIONNAIRE

\begin{tabular}{|l|l|c|l|}
\hline No. & \multicolumn{1}{|c|}{ Aspects } & $\begin{array}{c}\text { Practicality } \\
\text { Value }\end{array}$ & Criterion \\
\hline 1. & Presentation & $87,50 \%$ & Very practical \\
\hline 2. & Ease of use & $82,81 \%$ & Very practical \\
\hline 3. & Legibility & $89,07 \%$ & Very practical \\
\hline 4. & Readability & $81,25 \%$ & Very practical \\
\hline \multicolumn{2}{|l|}{ Rata-rata } & $85,16 \%$ & Very practical \\
\hline
\end{tabular}

Based on Table 1, it can be seen that the practical value of LKPD based on mental construction of APOS is $85,16 \%$ which is in very practical category. This means that according to students LKPD presentation is very practical, LKPD is also easy to use. Students generally think that LKPD uses language which is easy to understand and 
LKPD can also be completed in accordance with the given time.

\section{CONCLUSION}

Based on the result of research, it is found that LKPD based APOS has valid and practical from aspect of presentation, Ease of use, Readability, and Suitability of time

\section{REFERENCES}

[1] Muchtar, "Penerapan Model Pembelajaran ModificationAction, Prosess, Object, and Schema (M-APOS) untuk Meningkatkan Kemampuan Pemahaman Konsep Matematik Peserta didik," Skripsi, 2014.
[2] E. Wahyuning, "Pengembangan Kemampuan Komunikasi Matematik Siswa SMP dengan MEAs,," Jurnal Pendidikan, vol. XIV, pp. 1-10, 2013.

[3] E. \&. M. M. A. Dubinsky, "APOS: A Construktivist Theory of Learning in Undergraduate Mathematics Education Research,"pp. 275-282, 2001.

[4] H. Khatimah, "Pengembangan Lembar Kerja Peserta Didik Berdasarkan Teori Apos (Action, Processe, Object, Shceme) untuk Meningkatkan Efektivitas Pembelajaran Matematika," Edu-Sains, vol. IV, no. 2, 2015. 